\title{
A management framework for left sided endocarditis: a narrative review
}

\author{
Francesco Nappi ${ }^{1}$, Cristiano Spadaccio ${ }^{2,3}$, Marc R. Moon $^{4}$ \\ ${ }^{1}$ Department of Cardiac Surgery, Centre Cardiologique du Nord de Saint-Denis, Paris, France; ${ }^{2}$ Department of Cardiac Surgery, Golden Jubilee \\ National Hospital, Glasgow, UK; ${ }^{3}$ Institute of Cardiovascular and Medical Sciences, University of Glasgow, Glasgow, UK; ${ }^{4}$ Department of Cardiac \\ Thoracic Surgery, Washington University School of Medicine, St Louis, Missouri, USA \\ Contributions: (I) Conception and design: F Nappi; (II) Administrative support: None; (III) Provision of study materials or patients: None; (IV) \\ Collection and assembly of data: F Nappi; (V) Data analysis and interpretation: F Nappi; (VI) Manuscript writing: All authors; (VII) Final approval of \\ manuscript: All authors. \\ Correspondence to: Francesco Nappi, MD. Department of Cardiac Surgery, Centre Cardiologique du Nord, 36 Rue des Moulins Gémeaux, 93200 \\ Saint-Denis, Paris, France. Email: francesconappi2@gmail.com.
}

\begin{abstract}
Left sided endocarditis (LSE) can include the entirety or portion of mitral and/or aortic valve and the structures in their anatomical contiguity and represent a significant portion of emergency surgical activity. Literature and guidelines on the management of LSE relies mainly on observational studies given the difficulty in designing randomized trials in emergency settings. Heart teams (HT) are often called in to difficult decisions on the most appropriate strategy to adopted in case of LSE. Decision-making should take into account the localization and the extension of the infection, patient preoperative status and comorbidities, presence of a previous valve prosthesis and best timing for surgery. Despite evidence suggests that early surgery may improve survival in patients with complicated infective endocarditis (IE), an increased risk of recurrence and postoperative valvular dysfunctions has been reported. The most important factors associated with long-term outcomes are preoperative multiorgan failure, prosthetic mechanical valve IE, vegetation size $\geq 15 \mathrm{~mm}$, and timing of surgical treatment. Importantly, up to one third of potential candidates do not undergo surgery and these patients experience extremely high mortality rates. Another important point regards the choice of the optimal valve substitute to be used according to the different clinical situation. The lack of RCT in this field and the difficulty to design this type of studies in the case of non-elective conditions further complicates the possibility to achieve a univocal consensus on the best strategy to be adopted in each form of LSE and further validation studies are needed. On the basis of the current evidences a decisional algorithm is proposed summarizing all the crucial aspects in the management of LSE.
\end{abstract}

Keywords: Left side infective endocarditis; mechanical valves; biological substitute; guidelines; treatment and management

Submitted Jun 02, 2020. Accepted for publication Jul 19, 2020.

doi: 10.21037/atm-20-4439

View this article at: http://dx.doi.org/10.21037/atm-20-4439

\section{Introduction}

Left sided endocarditis (LSE) is an infection of the entirety or portion of mitral and/or aortic valve and the structures in their anatomical contiguity. It may be determined by various pathogens, but bacterial origin is the most common. In developed countries, LSE are one of the most common causes of acute valves failure. In some reports, the estimated annual prevalence of infective endocarditis (IE) was 3 to 9 cases per 100,000 persons $(1,2)$ and LSE affects native valves in $64 \%$ to $76.2 \%$ of the cases (3-5) and prosthetic valves in $89.9 \%$ (PVE) $(6,7)$.

In patients with LSE, age, evolutive cardiogenic shock, PVE, left ventricular ejection fraction (LVEF) $<40 \%$, and 
recurrent infections are considered significant predictors of mortality (6-9). However, current evidence regarding the treatment and management strategy for LSE are not univocal and are often based on empirical practice.

This report aims at reviewing the current evidences on LSE and provides a basis for the management of this disease focusing on aspects of the heart team (HT) approach, on the selection of the most appropriate surgical strategy and on the importance of physician-patient discussion about the risks, benefits, and expectations after the surgery.

We present the following article in accordance with the Narrative Review reporting checklist (available at http:// dx.doi.org/10.21037/atm-20-4439).

\section{Methods}

In December 2019, a search of the PubMed database using the terms "endocarditis", "left side endocarditis", "heart valve prosthesis", "allograft", "autograft", "cardiac valve surgery", "aortic valve replacement" was coordinated. Qualified abstracts were reviewed and the related articles were investigated. References for all selected studies were cross checked. Data from randomized controlled trials (RCT), unmatched observational series, observational series corresponding to propensity, meta-analysis, registries and expert opinion were included. It should be noted that weight of evidence regarding the different valve substitutes was not comparable among groups given the significantly larger number of observations for patients with xenograft $(\mathrm{N}=4,111)$, homografts $(\mathrm{N}=2,454)$ in comparison to mechanical prosthesis $(\mathrm{N}=655)$ Ross operation and valve repairs. Despite the majority of the observational studies are propensity matched, the lack of RCT and a number of other confounders limited the power of the analysis (Tables 1,2).

\section{Management of LSE}

\section{The approach}

In the 21 st century the central role of the multidisciplinary team emerged in the treatment of endocarditis and this is crucial for LSE management. Early diagnosis of the either native valve endocarditis (NVE) and PVE can favor both the optimization surgical timing and avoidance of potential complications.

Lack of multidisciplinary integration could lead to delay in diagnosis, late referral for surgery of patients in more critical conditions after failure of medical treatment.

In an Italian study, a formalized multidisciplinary team approach including (I) initial evaluation within the first 12 hours, (II) indication for early surgery within 48 hours and (III) a re-evaluation of the patient's clinical condition every week, led to a reduction in hospital mortality from $28 \%$ to $13 \%(\mathrm{P}=0.02)$ and in 3 -year mortality from $34 \% v s$. $16 \%(\mathrm{P}=0.0007)$, regardless age and comorbidities (38). The importance of tertiary centers with advanced surgical and management competencies is even more evident in complex LSE, and referral to these units can be advantageous not only in terms of clinical outcomes but also in terms of costeffectiveness for the national health systems. However, potential criticisms to this organizational model might regard the depletion of trained physicians in peripheral hospitals and the potential delays in transferring patients.

The treatment of IE in the current era requires a reconfiguration in the organizational standard towards a centralized system of care or, alternatively, the creation of a hub-and-speak model that is based on the activity of a multidisciplinary center reviewing clinical cases. This model would allow rapid and qualified initial management of IE and should be established on the basis of clinical evidence. There is no reason to doubt that the implementation of a centralized care can improve decision making, surgery timing, and short- and long-term results. Furthermore, the efficacy and validity of a centralized model could be readily tested in a study evaluating the difference between the before and after its creation (Figure 1).

\section{Risk assessment}

The risk assessment models for LSE aimed to assist the decision-making process of multidisciplinary team has a pivotal role during the discussion in HT (Figure 1, Table 3).

Gaca et al. (39) elaborated a surgical risk score for the IE based on the Society of Thoracic Surgeon's database. The authors identified 13 risk factors for mortality, including emergency status, cardiogenic shock, hemodialysis, and "active endocarditis".

Another single-center pilot study (40) included 440 patients who had the surgery for NVE and reported six predictors for early postoperative mortality. Variables were entered in a mathematical model with good predictivity [area under receiver operating characteristic curve (AUCROC) of 0.88]. The authors identified six predictors along with their assigned scores including age ( $5-13$ points), renal failure (5), NYHA class IV (9), critical preoperative 
Table 1 Observational studies and propensity matched comparing the allogenic and autologous substitute with conventional prosthesis

\begin{tabular}{|c|c|c|c|c|c|}
\hline First author (Ref.) & $\begin{array}{l}\text { Total } \\
\text { sample (N) }\end{array}$ & $\begin{array}{l}\text { Number of } \\
\text { patients/ } \\
\text { endocarditis }\end{array}$ & $\begin{array}{l}\text { Mean } \\
\text { follow-up/ } \\
\text { months }\end{array}$ & $\begin{array}{l}\text { Number of aortic } \\
\text { valve substitute } \\
\text { implanted or } \\
\text { repair }\end{array}$ & Main findings \\
\hline $\begin{array}{l}\text { Nappi 2018, } \\
\text { JTCVS (10) }\end{array}$ & 210 & 118 & 162 & $\begin{array}{l}\text { Ao-H [210]; } \chi \\
\text { Ao/Mitr-H [11] }\end{array}$ & $\begin{array}{l}\text { Similar survival at } 15 \text { years Ao-H }(61.3 \%) \text { vs. stented xenograft } \\
(62.1 \%) \text { and } v \text { s. mechanical prosthesis }(60.6 \%) ; 15 \text { years } \\
\text { freedom from reoperation SVD } 89.4 \% \text {. Freedom from IE } 98.1 \% \\
\text { at } 20 \text { years. MACCEs freedom from event at } 15 \text { years } 50.6 \%\end{array}$ \\
\hline $\begin{array}{l}\text { Kim 2016, } \\
\text { JTCVS (13) }\end{array}$ & $304^{\#}$ & 304 & 29.4 & $\begin{array}{l}\text { Ao-H [86]; MP } \\
{[79] ; \text { XP [139] }}\end{array}$ & $\begin{array}{l}\text { Similar survival between valve substitute. Odds ratio } 1.61 ; 95 \% \\
\text { confidence interval }(\mathrm{Cl}), 0.73-3.40, \mathrm{P}=0.23(\mathrm{HR} 1.10 ; 95 \% \mathrm{Cl} \text {, } \\
0.62-1.94, \mathrm{P}=0.75) \text {. Reinfection } 7.7 \% \text {. No difference in freedom } \\
\text { from reinfection rates }(\mathrm{P}=0.65) . \mathrm{CAH} \text { did not significantly affect } \\
\text { reinfection ( } \mathrm{HR} 1.04 ; 95 \% \mathrm{Cl}, 0.49-2.18, \mathrm{P}=0.93)\end{array}$ \\
\hline $\begin{array}{l}\text { Kim 2016, } \\
\text { JTCVS (14) }\end{array}$ & $436^{\#}$ & $\begin{array}{l}\text { IVDU 78; } \\
\text { Non-IVDU } \\
358\end{array}$ & 29.4 & $\begin{array}{l}\text { Ao-H [86]; MP } \\
\text { [99]; XP [206] }\end{array}$ & $\begin{array}{l}\text { Similar survival between group (IVDU vs. Non IDVU). (HR, 0.78; } \\
95 \% \mathrm{Cl}, 0.44-1.37) \text {. No difference between valve substitute. } \\
\text { Lower operative mortality in IVDUs (odds ratio, 0.25; 95\% } \\
\mathrm{Cl}, 0.06-0.71) \text {. Better valve-related complications in IVDUs } \\
(\mathrm{HR}, 3.82 ; 95 \% \mathrm{Cl}, 1.95-7.49 ; \mathrm{P}<0.001) \text { for higher rates of } \\
\text { reinfection (HR, } 6.20 ; 95 \% \mathrm{Cl}, 2.56-15.00 ; \mathrm{P}<0.001)\end{array}$ \\
\hline $\begin{array}{l}\text { Arabkhani 2016, } \\
\text { JTCVS (16) }\end{array}$ & 353 & 115 & 137 & Ao-H [115] & $\begin{array}{l}20 \text { years survival } 40.0 \% \text { at }(95 \% \mathrm{Cl}, 32-50 \%) .20 \text { years } \\
\text { predicted competing-risks analysis } 31 \% \text { death without } \\
\text { reoperation, } 39 \% \text { reoperation, and } 30 \% \text { alive without } \\
\text { reoperation. Low incidence of infection relapse }(3.96 \%) \text { and } \\
\text { reoperation }(2.26 \%)\end{array}$ \\
\hline $\begin{array}{l}\text { Flameng 2015, } \\
\text { Ann Thorac } \\
\text { Surg (17) }\end{array}$ & 69 & 69 & 96 & Ao-H [69] & $\begin{array}{l}10 \text { years survival } 73 \% .10 \text { years freedom of reoperation } 74 \% \text {. } \\
\text { Lower incidence of infection relapse and reoperation for IE } \\
(4.34 \%) . \text { Higher incidence of reoperation for SVD }(18.84 \%)\end{array}$ \\
\hline $\begin{array}{l}\text { Bourguignon } \\
2015, \text { Ann } \\
\text { Thorac Surg (18) }\end{array}$ & 2,559 & 111 & 79 & $\begin{array}{l}\mathrm{XP}[111] \text { (CP } \\
\text { bioprosthesis) }\end{array}$ & 15- and 20 -year survival $31.1 \%$ and $14.4 \%$ (95\% CI). IE early \\
\hline
\end{tabular}

Table 1 (continued) 
Table 1 (continued)

\begin{tabular}{|c|c|c|c|c|c|}
\hline First author (Ref.) & $\begin{array}{l}\text { Total } \\
\text { sample (N) }\end{array}$ & $\begin{array}{l}\text { Number of } \\
\text { patients/ } \\
\text { endocarditis }\end{array}$ & $\begin{array}{l}\text { Mean } \\
\text { follow-up/ } \\
\text { months }\end{array}$ & $\begin{array}{l}\text { Number of aortic } \\
\text { valve substitute } \\
\text { implanted or } \\
\text { repair }\end{array}$ & Main findings \\
\hline $\begin{array}{l}\text { Johnston } 2015 \text {, } \\
\text { Ann Thorac } \\
\text { Surg (19) }\end{array}$ & 12,569 & 450 & 68 & $\begin{array}{l}\mathrm{XP}[450](\mathrm{CP} \\
\text { bioprosthesis) }\end{array}$ & $\begin{array}{l}76 \% \text { probability of death before explant for SVD and } \\
\text { endocarditis at } 20 \text { years. Few probabilities of explantation for } \\
\text { SVD }(5.4 \%) \text { and endocarditis }(1.4 \%) \text { at } 20 \text { years }\end{array}$ \\
\hline $\begin{array}{l}\text { Hussain 2014, } \\
\text { JTCVS (21) }\end{array}$ & ${ }^{\#} 775$ & 537 & 84 & $\begin{array}{l}\text { Ao-H [357]; MP } \\
{[25] ; \text { XP [139] }}\end{array}$ & $\begin{array}{l}30 \text { days mortality } 7 \% \text { for aortic valve and } 14 \% \text { for aortic and } \\
\text { mitral valve IE. Survival at } 5 \text { years } 75 \% \text {. Rate of recurrence of } \\
\text { infection } 5.1 \%\end{array}$ \\
\hline $\begin{array}{l}\text { Sénage } 2014, \\
\text { Circulation (23) }\end{array}$ & 617 & & 44 & $\begin{array}{l}\text { XP [617] } \\
\text { Mitroflow } \\
\text { (models } 12 A / L X)\end{array}$ & $\begin{array}{l}5 \text { years survival } 69.6 \%(95 \% \mathrm{Cl}, 65.7-73.9) \text {. Early SVD. 1-, 2-, } \\
\text { and 5-year } 0.2 \%(95 \% \mathrm{Cl}, 0.0-0.6), 0.8 \% \text { (95\% Cl, 0.0-1.6), } \\
\text { and } 8.4 \%(95 \% \mathrm{Cl}, 5.3-11.3) .5 \text {-year SVD-free survival } 91.6 \% \\
(95 \% \mathrm{Cl}, 88.7-94.7) .13 \text { patients accelerated SVD }\end{array}$ \\
\hline $\begin{array}{l}\text { Glaser 2014, Ann } \\
\text { Thorac Surg (24) }\end{array}$ & 1,219 & 8 & 50 & $\begin{array}{l}\text { XP (CP 864); XP } \\
\text { (Mosaic 365) }\end{array}$ & $\begin{array}{l}\text { No difference } 8 \text { years survival } \mathrm{CP}(63 \%) \text { vs. Mosaic }(57 \%) \\
(\mathrm{P}=0.971) \text {. }(\mathrm{HR}, 0.85 ; 95 \% \mathrm{Cl}, 0.65-1.11) \text {. No difference in } \\
\text { reoperation }(\mathrm{P}=0.745) \text {. Lower incidence of IE recurrence }\end{array}$ \\
\hline $\begin{array}{l}\text { Manne 2012, } \\
\text { Ann Thorac } \\
\text { Surg (5) }\end{array}$ & 428 & 282 & 12 & $\begin{array}{l}\text { Ao-H [173]; MP } \\
\text { [24]; XP [84]; } \\
\text { Ross operation } \\
\text { [1]; Ao-R [12] }\end{array}$ & $\begin{array}{l}\text { Higher } 30 \text {-day mortality PVE vs. NVE ( } 13 \% \text { vs. } 5.6 \% \text {; } \\
\mathrm{P}<0.01) \text {. No difference in survival NVE vs. PVE }(35 \% \text { vs. } \\
29 \% ; \mathrm{P}=0.19) \text {. Higher } 30 \text { days mortality and } 1 \text { year mortality } \\
\text { for Staphylococcus aureus infection ( } 15 \% \text { vs. } 8.4 \% ; \mathrm{P}<0.05) \\
\text { and }(28 \% \text { vs. } 18 \% ; \mathrm{P}=0.02) . \text { Few reoperation for persistent } \\
\text { infection or relapse }(2.4 \%)\end{array}$ \\
\hline $\begin{array}{l}\text { Mayer 2012, Eur } \\
J \text { Cardiothorac } \\
\text { Surg (26) }\end{array}$ & 100 & 100 & 31 & $\begin{array}{l}\text { MP [10]; XP [51]; } \\
\text { Ross operation } \\
{[6] ; \text { Ao-R [33] }}\end{array}$ & $\begin{array}{l}\text { Similar } 30-\text { day mortality Ao-R 9\% vs. Ao-Rpl } 18 \%(P=0.37) \text {. } \\
\text { Better survival Ao-R ( } 88 \%) \text { vs. Ao-Rpl }(65 \%)(P=0.047) \text {. Higher } \\
\text { rate of reoperation Ao-R (35\%) vs. Ao-Rpl }(10 \%)(P=0.021)\end{array}$ \\
\hline $\begin{array}{l}\text { Bekkers } \\
\text { 2011, Eur J } \\
\text { Cardiothorac } \\
\text { Surg (27) }\end{array}$ & 262 & 96 & 102 & Ao-H [96] & $\begin{array}{l}30 \text {-day mortality } 5.7 \% \text {. Survival } 77.0 \%(95 \% \mathrm{Cl}, 71-83 \%) \text { at } \\
10 \text { years, and } 65.1 \%(95 \% \mathrm{Cl}, 57-74 \%) \text { at } 14 \text { years. Survival after } \\
\text { re-operation } 87.1 \% \text { at } 1 \text { year and } 79.3 \% \text { at } 9 \text { years. Freedom } \\
\text { from allograft re-operation } 82.9 \% \text { at } 10 \text { years and } 55.7 \% \\
\text { (SE } 5.7 \%) \text { at } 14 \text { years. SVD } 18.5 \% \text { and infection relapse } 0.7 \%\end{array}$ \\
\hline
\end{tabular}

Table 1 (continued) 
Table 1 (continued)

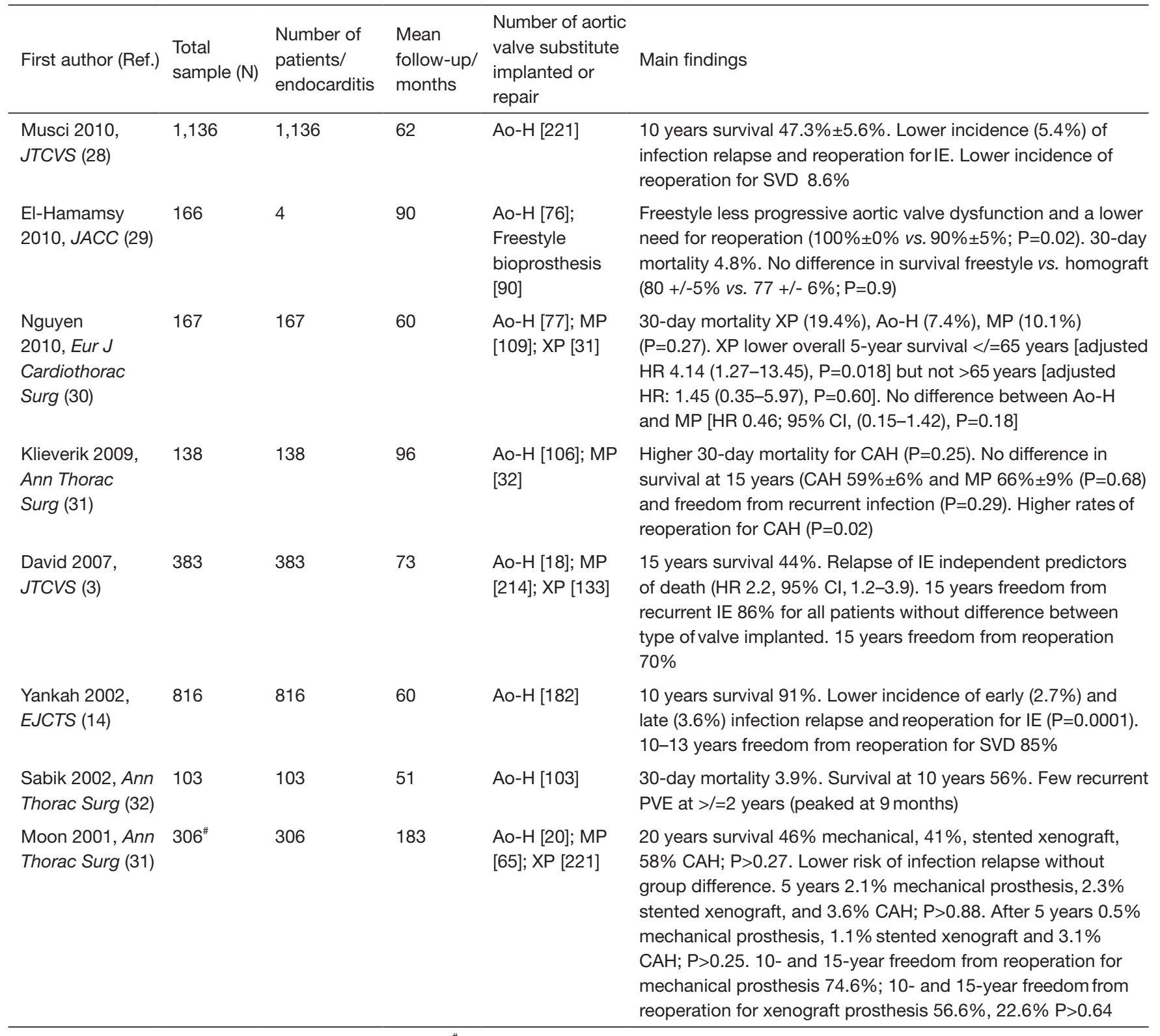

Of total $\mathrm{N}=436$ Valve repair was performed in $\mathrm{N}=45$. ", propensity score; $\chi$ Ao/Mitr- $\mathrm{H}$, cryopreserved mitro-aortic homograft replacement; IVDU, intravenous drug user.

status (39), failure to achieve preoperative blood culture negativity (5) and perivalvular involvement (5). They have outlined four risk classes ranging from "very low risk" ( $\leq 5$ points, expected average mortality of $1 \%)$, and "very high risk" ( $\geq 20$ points, mortality of $43 \%$ ).

Martínez-Sellés et al. (41) included 26 observational reports with over 1,000 patients treated for LSE (NVE $=315$ and PVE =122). They reported a significant reduction in in-hospital mortality in patients who underwent early surgery compared to those were managed with medical therapy (24.3\% vs. 34\%; $\mathrm{P}=0.02)$. A risk score called PALSUS was developed which aimed to evaluate hospital mortality using seven prognostic variables with a similar predictive value. Variables included were: prosthetic valve, age $\geq 70$, significant intracardiac destruction, Staphylococcus spp, urgent surgery, sex [female], EuroSCORE $\geq 10$ (42). 
Table 2 Meta-analysis and registries reporting the use of aortic homograft and conventional

\begin{tabular}{|c|c|c|c|c|c|}
\hline First author (Ref.) & $\begin{array}{l}\text { Total } \\
\text { sample (N) }\end{array}$ & $\begin{array}{l}\text { Number of } \\
\text { patients/ } \\
\text { endocarditis }\end{array}$ & $\begin{array}{l}\text { Mean follow-up/ } \\
\text { months }\end{array}$ & $\begin{array}{l}\text { Number of aortic } \\
\text { valve substitute } \\
\text { implanted }\end{array}$ & Main findings \\
\hline $\begin{array}{l}\text { Foroutan 2016, } \\
\text { BMJ (34) }\end{array}$ & 53,884 & - & $\begin{array}{l}\text { Cumulative incidence } \\
\text { of Death and SVD at } \\
10,15 \text { and } 20 \text { years }\end{array}$ & Xenograft $[53,884]$ & $\begin{array}{l}\text { Survival } 89.7 \%, 78.4 \%, 57.0 \% \text {, } \\
39.7 \% \text { and } 24.7 \% \text { at } 2,5,10 \text {, } \\
15 \text { and } 20.10,15 \text {, and } 20 \text { years } \\
\text { freedom from SVD } 94.0 \% \text {, } \\
81.7 \%, 52 \% \text { at (evaluated for } \\
7,603 \text { pts). SVD increases rapidly } \\
\text { after } 10 \text { years, and particularly } \\
\text { after } 15 \text { years }\end{array}$ \\
\hline $\begin{array}{l}\text { Savage 2014, Ann } \\
\text { Thorac Surg STS } \\
\text { database (35) }\end{array}$ & $\begin{array}{l}11,560 ; 8,491 \\
\text { prior, } 3,139 \\
\text { reoperative }\end{array}$ & 11,560 & 2005 to 2011 & $\begin{array}{l}\text { Ao-H [588]; XP } \\
{[5,396] ; \text { MP [2,144]; }} \\
\text { Other [293] }\end{array}$ & $\begin{array}{l}\text { AVR prior } 88.5 \% \text { vs. reoperative } \\
58.7 \% \text {; RR prior } 7.2 \% \text { vs. } \\
\text { reoperative } 29.9 \% \text {; Prior } \\
\text { operation XP increased }(57 \% \\
\text { to } 67 \%) \text { ). MP decreased ( } 30 \% \\
\text { vs. } 24 \% \text { ) Ao-H decreased ( } 9 \% \\
\text { vs. } 6 \% \text { ) P<0.001. Reoperation } \\
\text { XP increased ( } 38 \% \text { to } 52 \%) \\
\text { MP decreased ( } 20 \% \text { vs. } 17 \%) \\
\text { Ao-H decreased (38\% vs. } 28 \%) \\
\text { P }<0.001 \text {. Ao-H most used in } \\
\text { reoperation }\end{array}$ \\
\hline $\begin{array}{l}{ }^{\dagger} \text { Brennan 2013, } \\
\text { Circulation (37) }\end{array}$ & 39,190 & 452 & 150 & XP [644]; MP [376] & $\begin{array}{l}\text { No difference in survival (HR, } \\
1.04 ; 95 \% \mathrm{Cl}, 1.01-1.07) \text {. } \\
\text { XP higher reoperation (HR, } \\
2.55 ; 95 \% \mathrm{Cl}, 2.14-3.03) \text { and } \\
\text { endocarditis (HR, 1.60; 95\% } \\
\mathrm{Cl}, 1.31-1.94) \text {, and lower risks } \\
\text { for stroke (HR, 0.87; 95\% Cl, } \\
0.82-0.93) \text { and bleeding (HR, } \\
0.66 ; 95 \% \mathrm{Cl}, 0.62-0.70)\end{array}$ \\
\hline
\end{tabular}

\footnotetext{
${ }^{\dagger}, \mathrm{PM}$; ", all Ross operation.
} 


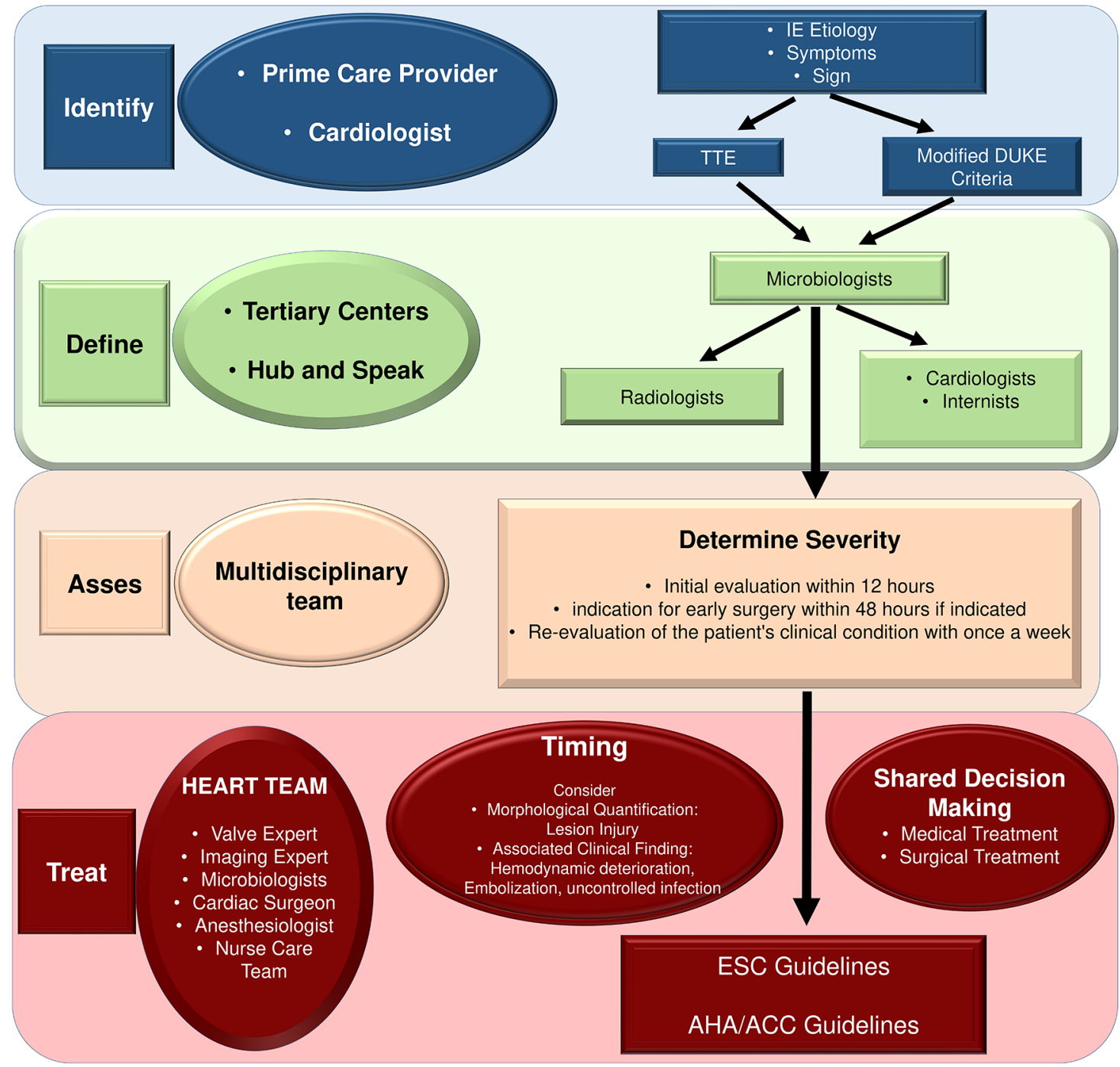

Figure 1 Clinical evaluation and diagnosis flowchart for LSE. For detailed explanation and references see text. ACC/AHA, American College of Cardiology/American Heart association; ESC, European Society of Cardiologists; IE, infective endocarditis; LSE, left side endocarditis; TTE, transthoracic echocardiography.

Hospital mortality ranged from $0 \%$ in patients with a PALSUSE score from 0 to $45.4 \%$ in patients with a PALSUSE score $>3$. Since the prognosis for IE surgery is highly variable, the PALSUSE score could help identify patients with higher hospital mortality.

\section{Timing of surgery}

The timing of surgery, especially in emergency status, is a lively topic of discussion in the HT and is often opposed to the use of medical treatment. The Heart Team works on the path laid out by the European Society of Cardiology (43) and AHA (44) who have classified the appropriate timing for surgery based on class and level of evidence (Figure 2, Table 3). The guidelines often do not correlate with real world scenarios faced by the multidisciplinary team. Chu et al. (45) highlighted that the main predictive factors for non-surgical referral were liver diseases [odds ratio (OR) for surgery: 0.16 ; $95 \%$ CI: 0.04 to 0.64$]$, S aureus infection (OR: $0.50 ; 95 \%$ CI: 0.30 to 0.85 ) and stroke prior to surgical decision (OR: 0.54 ; $95 \%$ CI: 0.32 to 0.90 ). In contrast, patients with severe aortic regurgitation, abscess 
Table 3 Timing for surgery based on guidelines based evidence and clinical situation

\begin{tabular}{|c|c|c|}
\hline Clinical situation & Surgical timing & Level of evidence \\
\hline $\begin{array}{l}\text { Minor cerebral event (transient ischemic attach of silent } \\
\text { cerebral embolism) }\end{array}$ & Immediate intervention required & Class I, level B \\
\hline Stroke without evidence of cerebral hemorrhage or coma & Immediate intervention possible & Class Ila, level B \\
\hline $\begin{array}{l}\text { Stroke with suspicion of intracranial hemorrhage or cerebral } \\
\text { septic emboli with potential hemorrhagic evolution }\end{array}$ & Defer surgery for 1 month; Obtain CT scan & Class I, level C \\
\hline
\end{tabular}

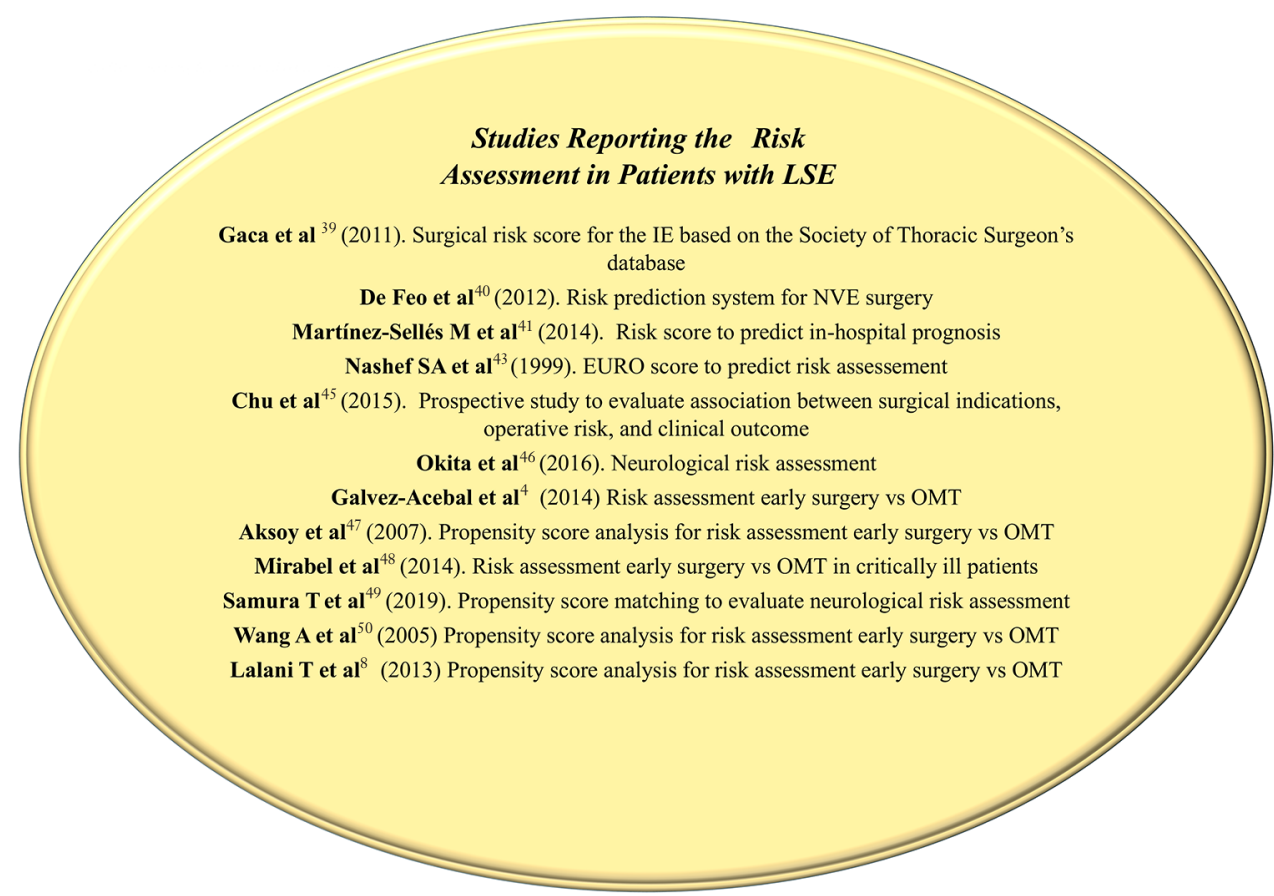

Figure 2 Studies reporting the risk assessment in patients with LSE (4,8,39-42,45-50). NVE, native valve endocarditis; OMT, optimal medical therapy; ACC/AHA, American College of Cardiology/American Heart association; ESC, European Society of Cardiologists; IE, infective endocarditis; LSE, left side endocarditis; TTE, transthoracic echocardiography.

and embolization were likely to undergo surgery. The authors concluded that surgical decision making in LSE is largely consistent with established guidelines, however nearly a quarter of patients with surgical indications did not receive surgery. Furthermore, evidence shows that the presence of the pathogen S. aureus in LSE was significantly associated with non-surgical management (45). The STS-IE score provides prognostic information for survival after the operative period, but a significant proportion of operations are actually never performed.

In LSE the timing of surgical treatment is closely related to the appearance of the neurological complication. In patients with stroke, surgery should not be postponed in the absence of coma and cerebral hemorrhage (class IIa, level B). The diagnosis of minor neurological events, such as the appearance of a transient ischemic attack or silent cerebral embolism, are criteria to recommend surgery without delay (class 1, level B) (43).

In contrast, the manifestation of devastating neurological events, such as intracranial hemorrhage and brain localization of septic emboli with an CT features indicating hemorrhagic evolution, should delay surgery by at least 1 month. According to the guidelines, repeated CT scans or MRI perfusion scans allow to evaluate the progression of 
the lesion (class IIa, level B) (43).

Okita et al. (46) retrospectively reported a multicenter cohort of 568 patients undergoing surgery for active LSE. Of those 118 patients had non-haemorrhagic cerebral infarction, 54 had intracranial hemorrhage and 396 had no brain events. Patients with non-haemorrhagic injury in which surgery was postponed for 2 weeks after the neurologic event had a higher incidence of hospital death. In particular, patients who were operated between 15 and 28 days or after 29 days from the onset of non-haemorrhagic cerebral infarction had higher incidences of hospital death compared with those who had surgery within 7 days. [Odds ratio $5.90(\mathrm{P}=0.107)$ and $4.92(\mathrm{P}=0.137)]$. Conversely, in presence of intracranial hemorrhage, patients who received surgery between 8 and 21 days or after 22 days had lower incidences of hospital mortality compared to early surgery (within 7 days) [odds ratio $0.79(\mathrm{P}=0.843)$ and 0.12 $(\mathrm{P}=0.200)]$.

Another decisive point of discussion is related to the priority between early surgery and antibiotics in the treatment of LSD complicated by heart failure, risk of embolization or in case of extensive infection. In the past 9 years, several large studies have supported the survival benefit associated with the use of early surgery in patients with LSE in larger studies with long-term follow-up.

Gálvez-Acebal et al. (4) in a propensity matched study on 417 patients with LSE with a mean follow-up was $1.3 \pm 21$ years showed that early surgery within 48 hours of diagnosis had a significantly better in-hospital mortality and late mortality rate than those managed conservatively with antibiotics [26.8\% vs. 41.8\%; absolute risk reduction (ARR), $-15.2 \% ; \mathrm{P}=0.004$ and $29.7 \%$ vs. $46.2 \%$; ARR, $-16.5 \%$; $\mathrm{P}=0.002$, respectively]. This study clearly supported the benefit of surgical treatment of left-sided IE especially in patients in which moderate or severe heart failure and paravalvular extension of infection occurred (4).

In another propensity match study from Duke university (47), on 426 patients with LSE the mortality rate associated with early surgical management was decreased (HR, 0.27; 95\% CI, 0.13-0.55). Patients who had an early surgical treatment were more likely to have Staphylococcus aureus infections, congestive heart failure, larger vegetations, intracardiac abscess, and undergoing hemodialysis without a chronic intravascular access. Diabetes mellitus (HR, 4.81; 95\% CI, 2.41-9.62), the presence of chronic intravenous catheters (HR, 2.65; 95\% CI, 1.31-5.33), and paravalvular complications (HR, 2.16;
95\% CI, 1.06-4.44) were risk factors for mortality

Mirabel et al. (48) included 198 patients who were prospectively evaluated for IE across 33 adult intensive care units (ICU) in France, and reported a 69\% longterm mortality at median follow-up time of 59.5 months in critical LSE. Sepsis-related Organ-Failure Assessment score (SOFA) calculated the day of surgery was the only factor independently associated with long-term mortality (HR $=1.59 ; 95 \%$ CI, $0.77-3.28$ for SOFA $5-9 ; 3.56,1.71-7.38$ for SOFA $10-14$ and $11.58,4.02-33.35$ for SOFA 15-20; reference category SOFA $0-4 ; \mathrm{P}<0.003)$.

Samura et al. (49) evaluated the impact of emergency surgery in 152 patients (45 propensity score-matched pairs) with left-sided native valve IE complicated with acute cerebral infarction. The authors reported a significant higher hospital mortality in patients who underwent delayed surgery compared to those who received early valve operation ( $16 \%$ vs. $2 \% ; \mathrm{P}=0.058)$. The survival rates at 5 years in patients who were managed with early valve operation was higher than in delayed surgery $[97 \%$ vs. $80 \%$, $(\mathrm{P}=0.029)]$.

Wang et al. (50) compared the effect of early surgery in patients with prosthetic valve IE in relation to age, causative microorganism, intracardiac abscess, and congestive heart failure. Surgery group $(\mathrm{n}=145)$ was associated with higher survival rates than the antimicrobial therapy group $(n=207)$ (OR for death, 0.56; 95\% CI, 0.23-1.36). Predictive factors of in-hospital mortality were brain embolization (OR 11.12; 95\% CI, 4.16-29.73) and Staphylococcus aureus infection (OR 3.67; 95\% CI, 1.29-9.74).

In a study from Cleveland Clinic (5), surgery for PVE $(\mathrm{n}=180)$ was compared to NVE $(\mathrm{n}=248)$ in 428 consecutive patients who were followed for a maximum of 5 years. Inhospital mortality was higher in PVE $v s$. NVE group (13\% vs. $5.6 \%$ ) and, after multivariate analysis, Staphylococcus aureus infection was the only independent predictors of inhospital death $(15 \%$ vs. $8.4 \% ; \mathrm{P}<0.05)$, 6-month (23\% vs. $15 \% ; \mathrm{P}=0.05)$ and 1 -year mortality ( $28 \%$ vs. $18 \% ; \mathrm{P}=0.02)$. There was a non-significant survival benefit in the PVE group in respect to NVE (35\% vs. 29\%; $\mathrm{P}=0.19)$.

In large propensity matched study from the International Collaboration on Endocarditis-Prospective Cohort Study Investigators (8), including 1,025 PVE patients (aortic valve, $71 \%$; mitral valve, $45.1 \%$ ), there was no significant difference in 30-day and 1 year survival in the early valve replacement group compared with medical therapy (HR for death, 0.44; 95\% CI, 0.38-0.52, $\mathrm{P}<0.001$ and 0.57 ; $95 \%$ CI, 
$0.49-0.67, \mathrm{P}<0.001)$.

\section{Surgery for LSE}

\section{Current trends in the surgical practice}

The surgery of endocarditis has been regarded as the most effective strategy for several categories of patients affected by the LSE. Long-term substitute durability is the key factor for the success of the surgery in patients with LSE $(10,21,22,28,35,51-53)$. To date, no definitive guidelines support the selection of one substitute over the other, and the choice of the best valve remained more a matter of art than of science. In the last 4 decades several substitutes have been proposed, 5 have passed the test of time with different success: homograft, autograft, stented or non-stented xenograft prosthesis and mechanical prosthesis.

Currently, the clinical benefits of using conventional biological prosthesis to replace an infected heart valve are well established, and this surgical option represents the tenet of modern valve surgery. Despite robust evidence suggests that the use of a biological valve, rather than mechanical prosthesis, is associated with further advantage in long-term outcomes, the effectiveness and safety of each substitute is related to the age and location of the implant $(18,19,24,33,34)$. For mitral valve mechanical valve represent still an adequate choice in patients up to 70 years old (54), while the benefit of aortic mechanical prosthesis disappears after 55 years of age $(38,39)$. The benefit in terms of lower risk of reoperation with mechanical valves is counterbalanced by the higher risk of bleeding and stroke in some age groups $(20,54)$.

Evidence suggests that the choice of a homograft or an autograft is useful in younger high-risk patients, such as those with complex valve endocarditis or in patients with PVE. The benefit of their use becomes more evident within the first post-operative decade because of the reduced risk of recurrent infection $(10,15-17,22,32,52,53)$. However, the risk of structural valve deterioration increases with time $(10,16,22,25,27)$. The use of cryopreserved homograft does not change the extent of the survival advantage (13). Nevertheless, the surgical community seemed reluctant to a wider adoption to these substitutes for a number of reasons.

A recent analysis of the Society of Thoracic Surgeons (STS) database revealed that, in the United States, the use of stented xenograft prosthetic valves is increased and a total of 8,421 patients $(73 \%)$ with IE cases received a conventional biological valves, both for primary operations and reoperations, compared to 3,139 patients (27\%) who were managed with mechanical valves (35). The use of homograft is rare during the primary operation but is more common in patients requiring reoperation $(32.2 \%$ vs. $7.0 \%, \mathrm{P}<0.0001)$ and when extensive intervention on the aortic root is required (53.2\%) (35). An analysis of the trend of the last 2 decades, based on a significant amount of observational data, has showed that the use of homograft has decreased over time in cases of first-time replacement of the aortic valve (from $9.4 \%$ to $5.6 \%$ ) and for reoperations (from $37.5 \%$ to $28.5 \%$ ) (35).

The reasons for the low use of mechanical valves and homografts are complex and multifactorial. More than two decades ago data reported by Washington University of St Louis showed that $50 \%$ of patients with IE underwent surgery with mechanical prosthesis while since 2009 only $14 \%$ of the patients were treated with this type of valve. The evident change in the surgeons' attitude has been probably determined on the one hand by the reported trends towards better survival and complication rate with biological valves, and on the other, by the increase in re-hospitalization for clinical events related to anticoagulation-related problems in recipients of mechanical valves $(20,54)$. In this scenario, managing both the short term and the long-term adverse event, including the prevention of thrombotic complication, can be the drivers of the surgical decision-making process because of the potential economical implications for the institutions. In fact, the costs of managing valve thrombosis was estimated to exceed $\$ 30,000$ for a single event. The costs of acute management of embolism and anticoagulantrelated hemorrhage were between $\$ 8,000$ and $\$ 11,500$ (55).

\section{The use of homograft and allograft for LSE-when and bow}

The reluctance shown by surgeons for the widespread adoption of cryopreserved homograft in IE finds its roots in lack of RCT investigating the effective benefit of the use of these substitutes $(10,13,16,22,31,32,51,56,57)$. Evidence from several reports have reported no significant differences in overall mortality and infection recurrence when comparing mechanical versus biological substitutes (13,31,51,56,57). Klieverik et al. (56) revealed a similar rate of recurrent endocarditis in patients who underwent homografts or mechanical prosthesis implantation, but a lower freedom from reoperation (76\% vs. $93 \%$ respectively). Sabik et al. (32) showed that patients with prosthetic IE, including $78 \%$ with periannular and radical abscesses, had 
a freedom from recurrent infection of more than 2 years of $95 \%$ and an operating mortality of $3.9 \%$ when treated with a homograft. Although the risk of homograft root re-operation for structural valve deterioration is higher, reduced rate of reinfection was noted in the long-term follow-up (between 14 and 27 years) (10,16,17,22,25,27,53), probably due to their favorable responses to antibiotics (16,22).

Despite the survival benefits associated with the use of pulmonary autograft (PA) are well established (29,57-62), its use to replace the aortic valve is recommended only in the US guidelines (Class II b, Evidence Level C) (63) and not mentioned in the European guidelines (43). The use of autograft in the setting of the LSE has been considerably reduced because of the indisputable technical complexity in the execution of the Ross operation. The data from STS database have showed 3-fold increase in operative mortality with Ross operation compared with conventional AVR, probably as an effect of lack of experience of low volume of cases $(36,64)$. Despite these evident criticalities, the use of $\mathrm{PA}$ in patients with LSE is indicated at a young age or with contraindication for long-term anticoagulant treatment, in women of childbearing age, in PVE and in patients who choose this substitute for the type of style of life they lead (12,65-68). However, it should be taken into consideration that potential complications of this operation involve both the aortic and pulmonary valve and carry an additional clinical burden (69).

\section{Surgery in complex LSE}

Kim et al. (13) reported outcomes of 131 patients treated with extensive and radical surgery for LSE. Homografts but also mechanical valves or xenografts have been used in these cases. The authors found that abscess formation had an incidence of $43.09 \%$, which is higher than the mean frequency $(36-38 \%)$ for LSE of native valve $(10,21)$ and PV (58\%) reported by several international studies (3). Abscess formation was treated in $40.5 \%$ with a mechanical valve and in $29.5 \%$ with xenograft.

The selection of the type of graft to be used should be guided by several parameters including age, extension of the infection (especially to the mitral valve), involvement of other heart structures and resistance to infections. The latter is particularly important since redo surgery in case of reinfection is particularly demanding and burdened by increased perioperative risk and poor early and mid-term outcomes. It is noteworthy that reinfection of synthetic prostheses or prosthetic materials after complex endocarditis were reported as more daunting and technically demanding than reinfection occurring on a previous homograft (10,52,53,62,66-69) (Figure 3).

In this context, evidences on safety and durability of homograft has been widely reported. A pivotal study of Stanford University (31) revealed a reinfection rate of $2 \%$ at 10 years with the majority of the cases occurring following aortic valve endocarditis surgery within the first year. More recently, the group from Cleveland clinic confirmed the long-term durability and safety of homografts for LSE with the additional benefit of improved postoperative hemodynamics and ventricular remodeling. The fact that no difference in outcomes was demonstrated between mechanical and biological prostheses suggests that in complex endocarditis and in patients with extensive PVE, the choice of the use of an allogeneic tissue is a priority $(5,21)$.

There is currently a sizable body of evidence to support the use of homografts in the setting of complex LSE. A report (17) showed a low recurrence of endocarditis in homograft even in complex cases. The larger series by Erasmus group (16) showed very solid results in terms of mortality and durability. The authors published their follow-up at 27 years underlying the importance of homografts in complex endocarditis. Musci et al. (28) used a homograft aortic roots in active IE with periannular abscess formation in a large series of patients with LSE showing satisfactory early and long-term results. Finally, as reported by Perrotta (15) survival benefit with the use of a homograft is higher than in prosthetic valves (5-year cumulative survival $88 \%$ versus $66 \%$ in prostheses).

Although structural valve deterioration is considered the Achilles' heel responsible for the limited use of allogenic tissue $(10,25,27,68,69)$, relapse of infection represents a daunting problem in patients treated for complex active LSE and should be given consideration. Notably, the reoperation for a relapsing infection carries a higher mortality than the reoperation for structural valve deterioration or dysfunction of an aortic homograft inserted in aortic root position (4-10\%) $(10,69,70)$.

Another important point is the reinfection in presence of the synthetic material. The strong inflammatory reaction elicited by the foreign material constituting the stent of mechanical or biological prosthetic valves demands for extensive demolition and debridement increasing the complexity of the procedure. However, reoperation after previous homograft is considered less demanding 

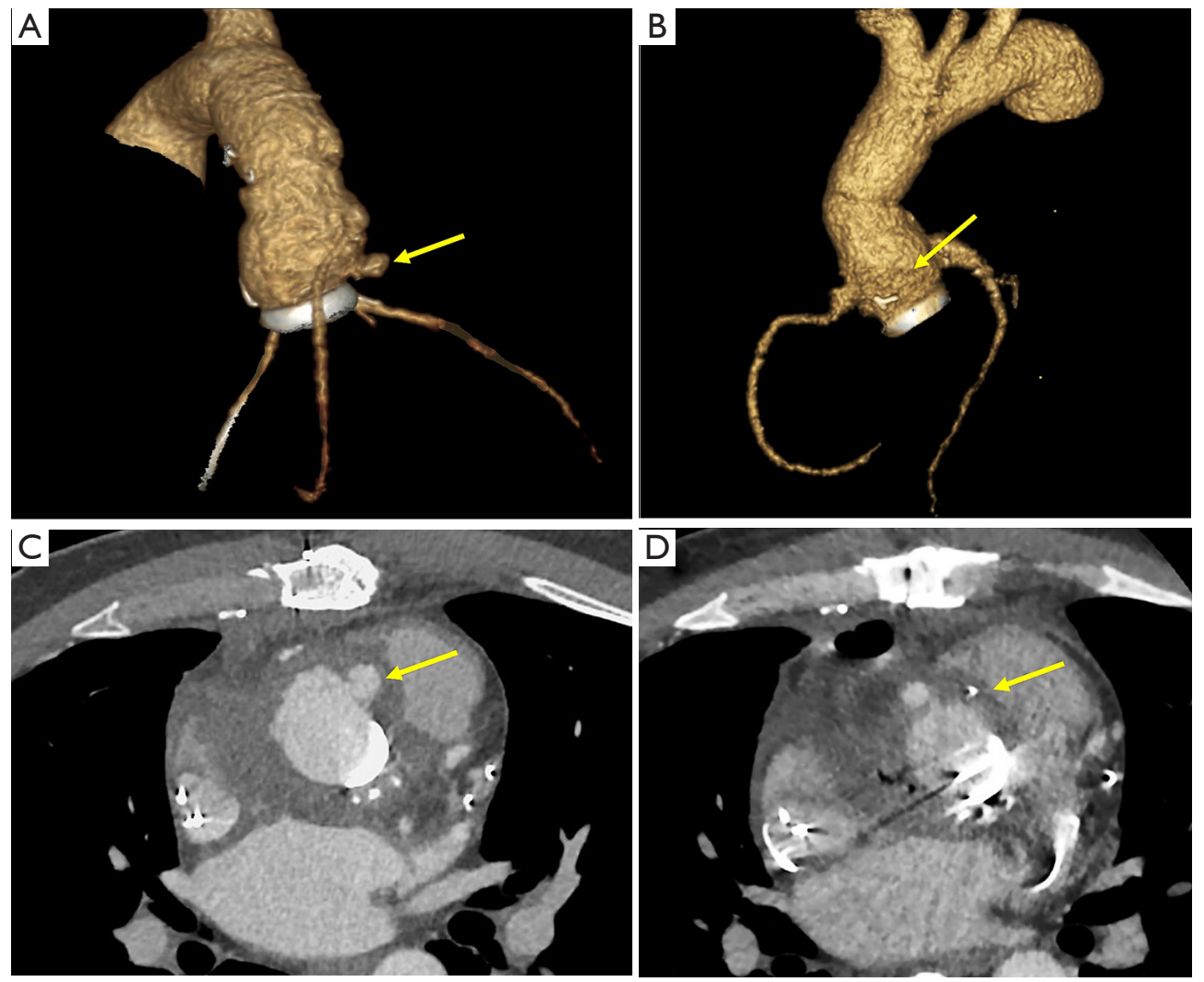

Figure 3 Aortic abscess (A,C) treated using a prosthetic valved conduit with mechanical valve (B,D).

even in the presence of massive calcification of the aortic $\operatorname{root}(71-73)$.

In LSE abscess formation is common. Avoiding the use of a homograft in favor of a prosthetic valve in aortic IE implies to treat the abscess with a circumferential patch to repair the ventricular-aortic discontinuity. Similarly, in the case of localized lesions involving only a part of the aortic annulus, the aorto-mitral continuity or aortic root, the cardiac structure still needs to be reconstituted with use of a partial Dacron or equine pericardial patch $(3,5,21,26,30,32)$. Recurrence of LSE involving the myocardium underlying the left coronary cusp is at even higher-risk and may require a Bentall or Cabrol operation.

Infection of more than one valve has been reported in $24.2 \%$ to $46.8 \%$ of the cases $(3,10,13,52)$ with mitral or tricuspid valve being more commonly involved in intravenous drugs user (11).

Clearly, complex LSE treated with prosthetic valves could lead to a further increase in the risk of mortality in the event of extensive reinfection of two prostheses $(3,26)$. In a very recent Harvard series, associated mitral valve involvement reached up $25 \%$ of the cases (13). We have proposed the use of a double homograft in complex LSE with extension to aorto-mitral junction and mitral including both total and partial mitral insertion techniques with satisfactory results at 18 years $(10,52,53,69)$.

\section{Surgery and ethical implication}

As recommended by current guidelines, selection of the most appropriate valve replacement strategy in LSE should consider the longevity of the biological substitutes, the potential recurrence of infection and the risk of redo surgery. The best choices are made through a shared decision-making process that includes the patient, the patient's family, an interventional cardiologist, a cardiac surgeon and, preferably, the patient's general cardiologist or general practitioner $(43,63)$. 
Patient's preferences and will also take a considerable part in the decision-making. Patients may be discouraged from large and demanding operation. Therefore, the role of the heart team is fundamental in providing detailed explanations of the indications, the steps of the procedure, the potential complications and the postoperative course to allow an informed decision-making. In educating the patient, the experts should explain the potential need for extensive debridement to obtain good and stable results. For example, proposing a faster operation by recommending a prosthetic valve instead of the use of autologous or allogenic tissue in the context of significant involvement of the aortic or mitral valves, can provide misleading information about a situation with a high potential for recurrence of infection. The decision on the surgical option and the choice of the ideal substitute always derives from a balance between the risk of the operation that the surgeon should perform and the obtainable benefit. In the case of complex LSE, both the risk of the procedure and the potentially even higher risk of a redo operation for infection relapse or valve degeneration should be taken into account. Obviously, these considerations are also ultimately subjected to the surgeon and unit's experience in complex procedures and the option of referral to tertiary centers should be explored according to the clinical conditions.

Interestingly, Stulak et al. (64) addressed the ethical problem after the use of autograft in Ross's operation. The use of biological derivatives in fact poses some ethical problems when the chances of procedure failure or reintervention are not negligible. The problem of durability of allogeneic and autologous tissues should be addressed with the patient during the counselling process. On the other hand, the benefit of low risk of infection relapse and the impact on quality of life related to the avoidance of lifelong anticoagulant therapy should be discussed.

\section{Take-home messages and an algorithm based on evidence}

The evidence discussed above indicates that modern LSE surgery should involve the use of a different strategies according to the location and extent of the infection. Conventional stented xenograft and mechanical prosthetic should be considered similar alternatives for localized LSE or combined with patch reconstruction in case of more abscess formation; mechanical valves should be preferred in cases of mitral valve endocarditis and biological valves should be used in patients older than 55 years of age in aortic position.

Due to its higher risk of structural valve deterioration, lack of availability and difficult learning curve, the use of homografts is limited to PVE or when complex reconstruction of the mitro-aortic curtain or aortic root is needed. The miniroot implant is probably the most adaptable technique for complicated LSE and most appropriate in case of demolitive surgery. Cryopreserved mitro-aortic tissue allows the complete or partial replacement of the mitral valve in case of aggressive lesions involving the trigones, the aortic root or cardiac and extracardiac fistulas. However, this type of surgical approach requires adequate surgeon's and center's experience.

The use of the autograft can be considered in young patients or in particular conditions such as women in childbearing age or in case of contraindications to longterm anticoagulation. The use of PA should be limited to centers that have proven experience with solid results and only to cases where a conventional biological or mechanical prosthesis is not indicated for clinical or technical reasons.

On the basis of the evidence examined in this study, we propose an algorithm assisting the choice of the valve substitute in different clinical conditions (Figures 4,5). In this algorithm, technical, anatomical and imaging determinants are considered, as well as the clinical characteristics of the patient, the orientation of the guidelines and institutions with the greatest experience in the treatment of LSE.

Due to the strong impact on post-operative mortality, special relevance should be given to timing, which influences the risk of neurological complications, and the extension of the infection. Despite evidence suggests that early surgery may improve survival in patients with complicated IE, an increased risk of recurrence and postoperative valvular dysfunctions has been reported $(6,11,14,23,26,30)$.

The most important factors associated with long-term outcomes are preoperative multiorgan failure, prosthetic mechanical valve IE, vegetation size $\geq 15 \mathrm{~mm}$, and timing of surgical treatment. Importantly, up to one third of potential candidates do not undergo surgery and these patients experience extremely high mortality rates $(37,74,75)$.

The lack of RCT in this field and the difficulty to design this type of studies in the case of non-elective conditions further complicates the possibility to achieve a univocal consensus on the best strategy to be adopted in each form 


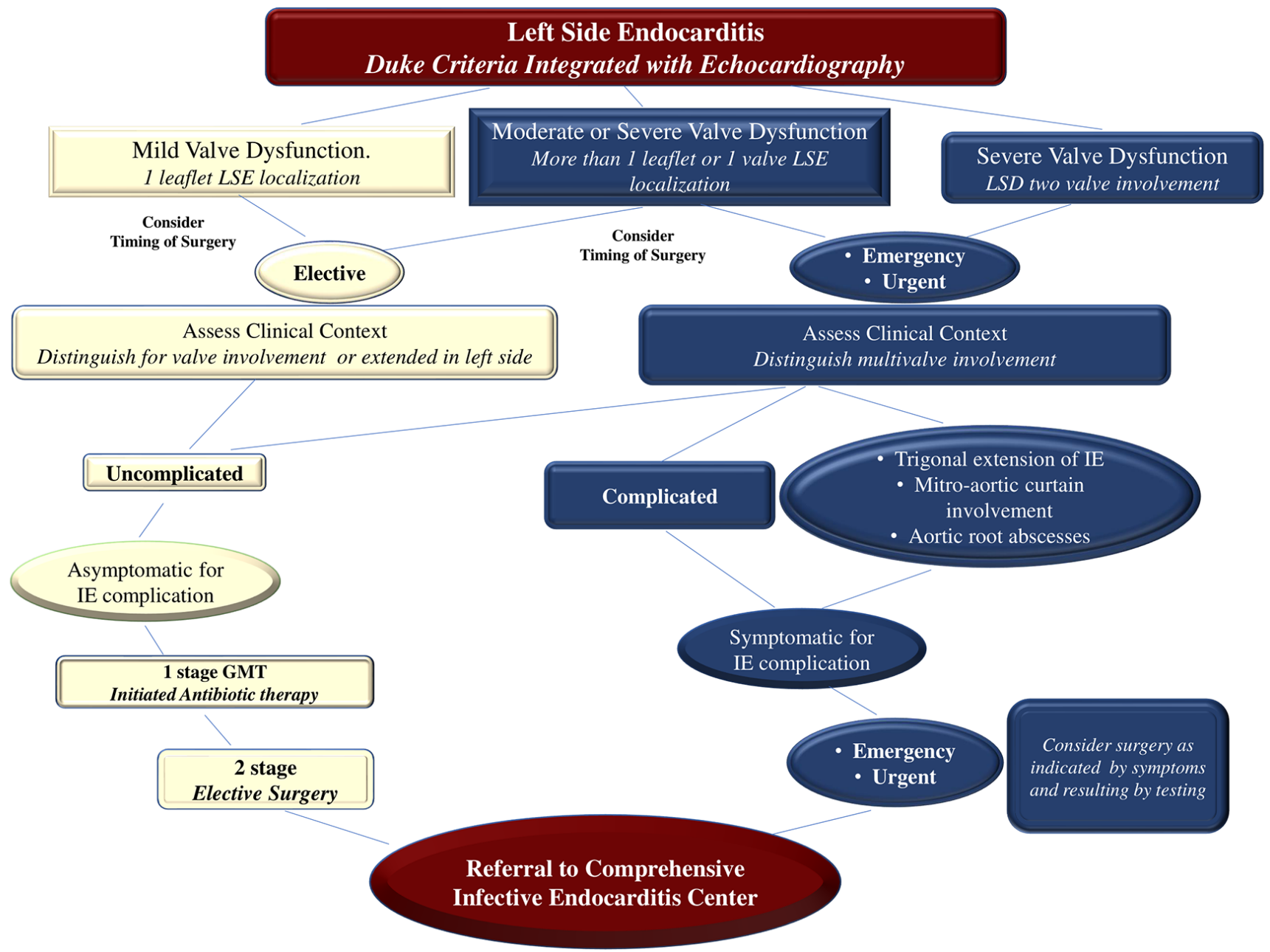

Figure 4 Take-Home Messages and Clinical Algorithm for the Management of Left Side Endocarditis. GMT, guide medical therapy; ACC/ AHA, American College of Cardiology/American Heart association; ESC, European Society of Cardiologists; IE, infective endocarditis; LSE, left side endocarditis; TTE, transthoracic echocardiography. 


\section{Candidate to Surgery for Left Side Endocarditis}

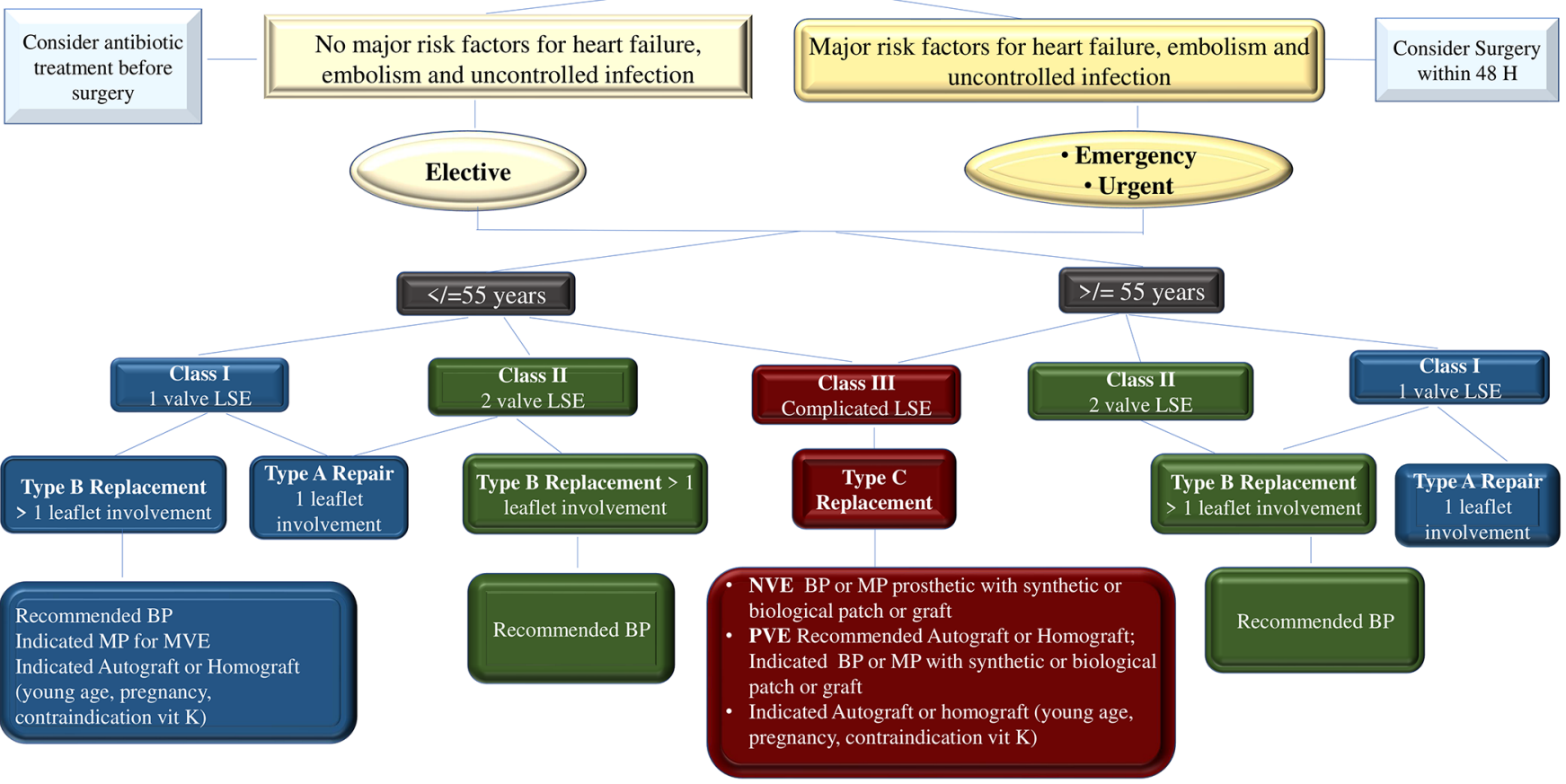

Figure 5 Take-home messages and clinical algorithm for the choice of optimal valve substitute for LSE. BP, bioprosthetic; MP, mechanical prosthetic; PVE, prosthetic valve endocarditis; ACC/AHA, American College of Cardiology/American Heart association; ESC, European Society of Cardiologists; IE, infective endocarditis; LSE, left side endocarditis; TTE, transthoracic echocardiography.

of LSE and further validation studies are needed.

\section{Acknowledgments}

Funding: None.

\section{Footnote}

Provenance and Peer Review: This article was commissioned by the Guest Editors (Drs. Francesco Nappi, Christos Mihos, and Cristiano Spadaccio) for the series "Infective Endocarditis in the 21st Century" published in Annals of Translational Medicine. The article was sent for external peer review organized by the Guest Editors and the editorial office.

Reporting Checklist: The authors have completed the Narrative Review reporting checklist. Available at http:// dx.doi.org/10.21037/atm-20-4439

Conflicts of Interest: The authors have completed the
ICMJE uniform disclosure form (available at http:// dx.doi.org/10.21037/atm-20-4439). The series "Infective Endocarditis in the 21st Century" was commissioned by the editorial office without any funding or sponsorship. FN served as the unpaid Guest Editor of the series and serves as an unpaid editorial board member of Annals of Translational Medicine from Feb 2019 to Jan 2021. CS served as the unpaid Guest Editor of the series. The authors have no other conflicts of interest to declare.

Ethical Statement: The authors are accountable for all aspects of the work in ensuring that questions related to the accuracy or integrity of any part of the work are appropriately investigated and resolved.

Open Access Statement: This is an Open Access article distributed in accordance with the Creative Commons Attribution-NonCommercial-NoDerivs 4.0 International License (CC BY-NC-ND 4.0), which permits the noncommercial replication and distribution of the article with the strict proviso that no changes or edits are made and the 
original work is properly cited (including links to both the formal publication through the relevant DOI and the license). See: https://creativecommons.org/licenses/by-nc-nd/4.0/.

\section{References}

1. Cahill TJ, Prendergast BD. Infective endocarditis. Lancet 2016;387:882-93.

2. Cahill TJ, Baddour LM, Habib G, et al. Challenges in Infective Endocarditis. J Am Coll Cardiol 2017;69:325-44.

3. David TE, Gavra G, Feindel CM, et al. Surgical treatment of active infective endocarditis: a continued challenge. J Thorac Cardiovasc Surg 2007;133:144-9.

4. Gálvez-Acebal J, Almendro-Delia M, Ruiz J, et al. Influence of early surgical treatment on the prognosis of left-sided infective endocarditis: a multicenter cohort study. Mayo Clin Proc 2014;89:1397-405.

5. Manne MB, Shrestha NK, Lytle BW, et al. Outcomes after surgical treatment of native and prosthetic valve infective endocarditis. Ann Thorac Surg 2012;93:489-93.

6. Grubitzsch H, Schaefer A, Melzer C, et al. Outcome after surgery for prosthetic valve endocarditis and the impact of preoperative treatment. J Thorac Cardiovasc Surg 2014;148:2052-9.

7. Alonso-Valle H, Fariñas-Alvarez C, García-Palomo JD, et al. Clinical course and predictors of death in prosthetic valve endocarditis over a 20-year period. J Thorac Cardiovasc Surg 2010;139:887-93.

8. Lalani T, Chu VH, Park LP, et al. In-hospital and 1-year mortality in patients undergoing early surgery for prosthetic valve endocarditis. JAMA Intern Med 2013;173:1495-504.

9. Gálvez-Acebal J, Rodríguez-Baño J, Martínez-Marcos FJ, et al. Prognostic factors in left-sided endocarditis: results from the Andalusian multicenter cohort. BMC Infect Dis 2010;10:17.

10. Nappi F, Nenna A, Petitti T, et al. Long-term outcome of cryopreserved allograft for aortic valve replacement. J Thorac Cardiovasc Surg 2018;156:1357-65.e6.

11. Schaefer A, Dickow J, Schoen G, et al. Stentless vs. stented bioprosthesis for aortic valve replacement: A case matched comparison of long-term follow-up and subgroup analysis of patients with native valve endocarditis. PLoS One 2018;13:e0191171.

12. Ratschiller T, Sames-Dolzer E, Paulus P, et al. Longterm Evaluation of the Ross Procedure in Acute Infective Endocarditis. Semin Thorac Cardiovasc Surg 2017. [Epub ahead of print].
13. Kim JB, Ejiofor JI, Yammine M, et al. Are homografts superior to conventional prosthetic valves in the setting of infective endocarditis involving the aortic valve? J Thorac Cardiovasc Surg 2016;151:1239-46, 48.e1-2.

14. Yankah AC, Klose H, Petzina R, et al. Surgical management of acute aortic root endocarditis with viable homograft: 13-year experience. Eur J Cardiothorac Surg 2002;21:260-7.

15. Perrotta S, Jeppsson A, Frojd V, et al. Surgical Treatment of Aortic Prosthetic Valve Endocarditis: A 20-Year SingleCenter Experience. Ann Thorac Surg 2016;101:1426-32.

16. Arabkhani B, Bekkers JA, Andrinopoulou ER, et al. Allografts in aortic position: Insights from a 27-year, single-center prospective study. J Thorac Cardiovasc Surg 2016;152:1572-9.e3.

17. Flameng W, Daenen W, Jashari R, et al. Durability of homografts used to treat complex aortic valve endocarditis. Ann Thorac Surg 2015;99:1234-8.

18. Bourguignon T, Bouquiaux-Stablo AL, Candolfi P, et al. Very long-term outcomes of the Carpentier-Edwards Perimount valve in aortic position. Ann Thorac Surg 2015;99:831-7.

19. Johnston DR, Soltesz EG, Vakil N, et al. Long-term durability of bioprosthetic aortic valves: implications from 12,569 implants. Ann Thorac Surg 2015;99:1239-47.

20. Chiang YP, Chikwe J, Moskowitz AJ, et al. Survival and long-term outcomes following bioprosthetic vs mechanical aortic valve replacement in patients aged 50 to 69 years. JAMA 2014;312:1323-9.

21. Hussain ST, Shrestha NK, Gordon SM, et al. Residual patient, anatomic, and surgical obstacles in treating active left-sided infective endocarditis. J Thorac Cardiovasc Surg 2014;148:981-8.e4.

22. Fukushima S, Tesar PJ, Pearse B, et al. Long-term clinical outcomes after aortic valve replacement using cryopreserved aortic allograft. J Thorac Cardiovasc Surg 2014;148:65-72.e2.

23. Sénage T, Le Tourneau T, Foucher Y, et al. Early structural valve deterioration of Mitroflow aortic bioprosthesis: mode, incidence, and impact on outcome in a large cohort of patients. Circulation 2014;130:2012-20.

24. Glaser N, Franco-Cereceda A, Sartipy U. Late survival after aortic valve replacement with the perimount versus the mosaic bioprosthesis. Ann Thorac Surg 2014;97:1314-20.

25. Kowert A, Vogt F, Beiras-Fernandez A, et al. Outcome after homograft redo operation in aortic position. Eur J Cardiothorac Surg 2012;41:404-8. 
26. Mayer K, Aicher D, Feldner S, et al. Repair versus replacement of the aortic valve in active infective endocarditis. Eur J Cardiothorac Surg 2012;42:122-7.

27. Bekkers JA, Klieverik LM, Raap GB, et al. Re-operations for aortic allograft root failure: experience from a 21year single-center prospective follow-up study. Eur J Cardiothorac Surg 2011;40:35-42.

28. Musci M, Weng Y, Hubler M, et al. Homograft aortic root replacement in native or prosthetic active infective endocarditis: twenty-year single-center experience. J Thorac Cardiovasc Surg 2010;139:665-73.

29. El-Hamamsy I, Eryigit Z, Stevens LM, et al. Longterm outcomes after autograft versus homograft aortic root replacement in adults with aortic valve disease: a randomised controlled trial. Lancet 2010;376:524-31.

30. Nguyen DT, Delahaye F, Obadia JF, et al. Aortic valve replacement for active infective endocarditis: 5-year survival comparison of bioprostheses, homografts and mechanical prostheses. Eur J Cardiothorac Surg 2010;37:1025-32.

31. Moon MR, Miller DC, Moore KA, et al. Treatment of endocarditis with valve replacement: the question of tissue versus mechanical prosthesis. Ann Thorac Surg 2001;71:1164-71.

32. Sabik JF, Lytle BW, Blackstone EH, et al. Aortic root replacement with cryopreserved allograft for prosthetic valve endocarditis. Ann Thorac Surg 2002;74:650-9; discussion 9.

33. Wang M, Furnary AP, Li HF, et al. Bioprosthetic Aortic Valve Durability: A Meta-Regression of Published Studies. Ann Thorac Surg 2017;104:1080-7.

34. Foroutan F, Guyatt GH, O'Brien K, et al. Prognosis after surgical replacement with a bioprosthetic aortic valve in patients with severe symptomatic aortic stenosis: systematic review of observational studies. BMJ 2016;354:i5065.

35. Savage EB, Saha-Chaudhuri P, Asher CR, et al. Outcomes and prosthesis choice for active aortic valve infective endocarditis: analysis of the Society of Thoracic Surgeons Adult Cardiac Surgery Database. Ann Thorac Surg 2014;98:806-14.

36. Reece TB, Welke KF, O'Brien S, et al. Rethinking the ross procedure in adults. Ann Thorac Surg 2014;97:175-81.

37. Brennan JM, Edwards FH, Zhao Y, et al. Long-term safety and effectiveness of mechanical versus biologic aortic valve prostheses in older patients: results from the Society of Thoracic Surgeons Adult Cardiac Surgery National Database. Circulation 2013;127:1647-55.
38. Chirillo F, Scotton P, Rocco F, et al. Impact of a multidisciplinary management strategy on the outcome of patients with native valve infective endocarditis. Am J Cardiol 2013;112:1171-6.

39. Gaca JG, Sheng S, Daneshmand MA, et al. Outcomes for endocarditis surgery in North America: a simplified risk scoring system. J Thorac Cardiovasc Surg 2011;141:98106.e1-2.

40. De Feo M, Cotrufo M, Carozza A, et al. The need for a specific risk prediction system in native valve infective endocarditis surgery. ScientificWorldJournal 2012;2012:307571.

41. Martínez-Sellés M, Muñoz P, Arnáiz A, et al. Valve surgery in active infective endocarditis: a simple score to predict in-hospital prognosis. Int J Cardiol 2014;175:133-7.

42. Nashef SA, Roques F, Michel P, et al. European system for cardiac operative risk evaluation (EuroSCORE). Eur J Cardiothorac Surg 1999;16:9-13.

43. Habib G, Lancellotti P, Antunes MJ, et al. 2015 ESC Guidelines for the management of infective endocarditis: The Task Force for the Management of Infective Endocarditis of the European Society of Cardiology (ESC). Endorsed by: European Association for Cardio-Thoracic Surgery (EACTS), the European Association of Nuclear Medicine (EANM). Eur Heart J 2015;36:3075-128.

44. Nishimura RA, Otto CM, Bonow RO, et al. 2017 AHA/ ACC Focused Update of the 2014 AHA/ACC Guideline for the Management of Patients With Valvular Heart Disease: A Report of the American College of Cardiology/ American Heart Association Task Force on Clinical Practice Guidelines. Circulation 2017;135:e1159-95.

45. Chu VH, Park LP, Athan E, et al. Association between surgical indications, operative risk, and clinical outcome in infective endocarditis: a prospective study from the International Collaboration on Endocarditis. Circulation 2015;131:131-40.

46. Okita Y, Minakata K, Yasuno S, et al. Optimal timing of surgery for active infective endocarditis with cerebral complications: a Japanese multicentre study. Eur J Cardiothorac Surg 2016;50:374-82.

47. Aksoy O, Sexton DJ, Wang A, et al. Early surgery in patients with infective endocarditis: a propensity score analysis. Clin Infect Dis 2007;44:364-72.

48. Mirabel M, Sonneville R, Hajage D, et al. Long-term outcomes and cardiac surgery in critically ill patients with infective endocarditis. Eur Heart J 2014;35:1195-204.

49. Samura T, Yoshioka D, Toda K, et al. Emergency valve 
surgery improves clinical results in patients with infective endocarditis complicated with acute cerebral infarction: analysis using propensity score matching $\dagger$. Eur J Cardiothorac Surg 2019;56:942-9.

50. Wang A, Pappas P, Anstrom KJ, et al. The use and effect of surgical therapy for prosthetic valve infective endocarditis: a propensity analysis of a multicenter, international cohort. Am Heart J 2005;150:1086-91.

51. Jassar AS, Bavaria JE, Szeto WY, et al. Graft selection for aortic root replacement in complex active endocarditis: does it matter? Ann Thorac Surg 2012;93:480-7.

52. Nappi F, Spadaccio C, Dreyfus J, et al. Mitral endocarditis: A new management framework. J Thorac Cardiovasc Surg 2018;156:1486-95.e4.

53. Nappi F, Spadaccio C, Acar C. Use of allogeneic tissue to treat infective valvular disease: Has everything been said? J Thorac Cardiovasc Surg 2017;153:824-8.

54. Goldstone AB, Chiu P, Baiocchi M, et al. Mechanical or Biologic Prostheses for Aortic-Valve and Mitral-Valve Replacement. N Engl J Med 2017;377:1847-57.

55. Caro JJ, Migliaccio-Walle K, O'Brien JA. The cost of treating heart valve related complications. J Heart Valve Dis 1996;5:122-7.

56. Klieverik LM, Yacoub MH, Edwards S, et al. Surgical treatment of active native aortic valve endocarditis with allografts and mechanical prostheses. Ann Thorac Surg 2009;88:1814-21.

57. Sievers HH, Stierle U, Petersen M, et al. Valve performance classification in 630 subcoronary Ross patients over 22 years. J Thorac Cardiovasc Surg 2018;156:79-86.e2.

58. Sievers HH, Stierle U, Charitos EI, et al. A multicentre evaluation of the autograft procedure for young patients undergoing aortic valve replacement: update on the German Ross registry. Eur J Cardiothorac Surg 2016;49:212-8.

59. Mazine A, David TE, Rao V, et al. Long-term outcomes of the Ross procedure versus mechanical aortic valve replacement: propensity-matched cohort study. Circulation 2016;134:576-85.

60. Nappi F, Spadaccio C, Al-Attar N, et al. The Ross procedure at the crossroads: lessons from biology: is Dr Ross's dream concluded? Int J Cardiol 2015;178:37-9.

61. Spadaccio C, Montagnani S, Acar C, et al. Introducing bioresorbable scaffolds into the show. A potential adjunct to resuscitate Ross procedure. Int J Cardiol 2015;190:50-2. 62. Nappi F, Spadaccio C, Chello M, et al. The Ross procedure: Underuse or under-comprehension? J Thorac Cardiovasc Surg 2015;149:1463-4.

63. Nishimura RA, Otto CM, Bonow RO, et al. 2017 AHA/ ACC Focused Update of the 2014 AHA/ACC Guideline for the Management of Patients With Valvular Heart Disease: A Report of the American College of Cardiology/ American Heart Association Task Force on Clinical Practice Guidelines. J Am Coll Cardiol 2017;70:252-89.

64. Stulak JM, Burkhart HM, Sundt TM, et al. Spectrum and outcome of reoperations after the Ross procedure. Circulation 2010;122:1153-8.

65. Chauvette V, Bouhout I, Lefebvre L, et al. The Ross procedure is a safe and durable option in adults with infective endocarditis: a multicentre study. Eur J Cardiothorac Surg 2020;58:537-43.

66. Nappi F, Nenna A, Larobina D, et al. Simulating the ideal geometrical and biomechanical parameters of the pulmonary autograft to prevent failure in the Ross operation. Interact Cardiovasc Thorac Surg 2018;27:269-76.

67. Nappi F, Avtaar Singh SS, Spadaccio C, et al. Ross operation 23 years after surgery: It should not be a "forgotten" option. J Card Surg 2020;35:952-6.

68. Nappi F, Singh SSA, Lusini M, et al. The use of allogenic and autologous tissue to treat aortic valve endocarditis. Ann Transl Med 2019; 7:491.

69. Olivito S, Lalande S, Nappi F, et al. Structural deterioration of the cryopreserved mitral homograft valve. J Thorac Cardiovasc Surg 2012;144:313-20, 320.e1.

70. Joudinaud TM, Baron F, Raffoul R, et al. Redo aortic root surgery for failure of an aortic homograft is a major technical challenge. Eur J Cardiothorac Surg 2008;33:989-94.

71. Onorati F, Biancari F, De Feo M, et al. Mid-term Results of Aortic Valve Surgery in Redo Scenarios in the Current Practice: Results From the Multicentre European RECORD (REdo Cardiac Operation Research Database) Initiative†. Eur J Cardiothorac Surg 2015;47:269-80; discussion 280.

72. Potter DD, Sundt TM 3rd, Zehr KJ, et al. Operative Risk of Reoperative Aortic Valve Replacement. J Thorac Cardiovasc Surg 2005;129:94-103.

73. Salaun E, Mahjoub H, Girerd N, et al. Rate, Timing, Correlates, and Outcomes of Hemodynamic Valve Deterioration After Bioprosthetic Surgical Aortic Valve Replacement. Circulation 2018;138:971-85.

74. Kim JB, Ejiofor JI, Yammine M, et al. Surgical outcomes 
of infective endocarditis among intravenous drug users. J Thorac Cardiovasc Surg 2016;152:832-41.e1.

75. Thuny F, Beurtheret S, Mancini J, et al. The timing of

Cite this article as: Nappi F, Spadaccio C, Moon MR. A management framework for left sided endocarditis: a narrative review. Ann Transl Med 2020;8(23):1627. doi: 10.21037/atm-204439 surgery influences mortality and morbidity in adults with severe complicated infective endocarditis: a propensity analysis. Eur Heart J 2011;32:2027-33. 